\title{
The Queerness of Black Matriarchal Praxis
}

\author{
Theresa Hice-Fromille \\ Department of Sociology, University of California, Santa Cruz, 1156 High Street Santa Cruz, \\ California, 95064 \\ Corresponding author. thmajohn@ucsc.edu
}

(Received 21 August 2019; revised 15 January 2021; accepted 16 February 2021)

\section{In Need of a Mother}

I met Kyla ${ }^{1}$ at a small conference on a rainy weekend in February 2018. I wandered into the workshop shortly after it had started, and the room was filled with Black women designing vision boards. Kyla didn't stop what she was doing as she replied to the question the presenter posed to the room. Her hands continued moving, cutting glossy paper or pasting shiny gems onto her board: "When I tell people that my organization raises money to take girls abroad, so many of them say, 'Well why wouldn't you raise money for them to buy clothes or eat. They need food and education before they need to travel.' But I always say, 'But what about Black joy?'”

She exhales as she says this last piece. The words echo in my ears. But what about Black joy? I listen intently to the other words shared throughout the workshop, but my limbs itch with the desire to move toward her. I am thinking about how I can approach this woman and ask her about this organization. This organization that enables Black girls to travel. This organization that centers Black joy.

As a Black mother without a Black mother I have carefully watched Kyla, looking to her for guidance on how to mother my Black daughter and how to maintain my role in academia as one that is motivated by community liberation rather than individual success. Kyla's Black matriarchal praxis focuses material efforts on the protection of Black joy and exemplifies the ways that contemporary social movements have adapted the knowledge of our ancestors through the process of Black mothering. By founding and directing a Black youth-centered community organization and subsequently mothering systemically oppressed Black youth from her two chocolate-city hometownsMiami and Oakland-as well as lovingly adopting her partner's four children, Kyla has shown me how Black mothering is equally a carefully accepted community commitment and unquestionably queer.

Here, I place Kyla's own words at the start of each section to ground myself in what I have learned from her and to highlight my process of understanding Black matriarchal praxis. ${ }^{2}$ Kyla and other contemporary leaders within the movement for Black lives have conjured a praxis that traverses time and space. They conjure the healing knowledge passed down by radical Black women including such known figures as Ida B. Wells-Barnett and Ella Baker as well as those wayward women who remain defiantly anonymous. Black matriarchal praxis beckons the submerged queerness inseparable

(c) The Author(s), 2021. Published by Cambridge University Press on behalf of Hypatia, a Nonprofit Corporation. This is an Open Access article, distributed under the terms of the Creative Commons Attribution licence (http://creativecommons.org/licenses/by/4.0/), which permits unrestricted re-use, distribution, and reproduction in any medium, provided the original work is properly cited. 
from Blackness and orients the movement toward a requisite of Black liberation: young people and their ability to hold joy.

\section{Subjugation: Slavery and Its Afterlives}

I remember thinking I wish I had a language to speak. . I remember telling my grandma that and that like set my grandma off and she said, "Well you do have a language and ... the fact that we could take slave languages and make them into this beautiful thing is something to celebrate." ['C]ause often we hear the story of Black people being embarrassed or feeling bad [about African American Vernacular English] and my grandma was so proud of how she spoke and how her mother spoke and that gave me a pride. This is really beautiful and Black people are very creative in the face of death.-Kyla

The Atlantic slave trade was meant to break the captured African-crush her under the weight of Enlightened racialization. "That is what slavery did," Mother Saidiya Hartman has observed, "it stripped your history to bare facts and precious details" (Hartman 2007, 11). At the core of this lost history was the kinship abandoned on the shores of the Gold Coast. There was no Black family upon arrival in the New World. There was no Black woman, Black man, and certainly no Black child. Indeed, a Black child would have meant a Black future, and that was a definite impossibility. Instead, the Black child emerged marked as a commodity, never to belong to her mother. We carry that mark today.

Throughout the existence of North American slavery, the law of partus sequitur ventrum - that which is brought forth follows the womb-"negated kinship and denied it any "legal or social efficacy"' (Hartman 2016, 168). Partus sequitur ventrum marked the Black child, ruinously carved the raised hieroglyphics of her flesh, to be passed on to her children and her children's children. The ungendered slave could never be a mother. Her precarious position, one in which her offspring could be ripped away at any moment, made it so the sacredness of motherhood "as female blood-rite/right" was stripped from her (Spillers 1987, 75). The alchemy of enslavement-transforming people into property-illegitimized Black kinship and necessitated the severance of the enslaved mother from her child.

Psychological bonding, as described by Frederick Douglass and taken up by Mother Hortense Spillers, required the presence of the mother. Without her, any remaining familial/blood relations disintegrated. Just as slavery reduced the African woman's body to flesh ungendered, it rendered her unmothered. The designation of the ungendered female as available for invasion/raiding by the plantation holders created a position of precarity in which she was unable to maintain kinship ties. Family, then, became the "mythically revered privilege of a free and freed community" (Spillers 1987, 74). The enslaved Black family does not exist.

I, too, entered this world, with raised hieroglyphics of the flesh, inherited trauma, and without a [Black] family. I asked to be nursed so frequently and for such prolonged durations that my mother was forced to deny me her breast a few short months after delivering me. "She feels the instability of her environment," the doctor said. I felt the precarity of my placement in this world, I think. Born without a Black mother to guide my first footsteps and my [father's] Blackness caged, a casualty of mass incarceration, I was left questioning the significance of my placement. Was my birth a reiteration of the denial of a family - a reconceptualization of the negation of kinship, adjusted 
to accommodate the impossible narrative of race mixture that is enveloped in the epochal articulation of liberal anti-Blackness? And more important, does this denial correspond with my permanent isolation from the liberatory potential of Blackness? Which is to say, without a Black mother am I destined to wander alone?

There was a time when I may have conceded to this seeming inevitability. Yet Kyla's demonstration of the possibility of survival that is cradled within a Black matriarchal praxis has enabled me to regain my footing and remember that with which I am tasked. The queerness of this praxis rejects a heteropatriarchal politics of sexuality that would use the cover of racial purity to dismiss my yearning for a place within the Black family. By refuting the biological racial schema that upholds notions of racial inheritance, the queered kinship enacted by Black matriarchal praxis locates me and calls me home.

\section{Survival: The Village}

[Before my mom died] I was taking care of my mom, she had my sister. My sister was then my child and I was like 10-and it was just a lot of things happening in my world and I think that happens for a lot of Black girls-you just have to grow up. Like, you don't get to be a girl, so you are doing all of these womanly things ... I remember my aunt saying, "But you're so grown"-but it's like but y'all are making me grow up...-Kyla

In her analysis of a scene involving two (queer) Black students that played out in a San Francisco high school hallway, Auntie Savannah Shange writes, "Here, to be a man is to beat a woman, laying bare the range of antagonisms that lie within the frame of The Black Family, and the constrained set of choices masquerading as the 'agency' available to Black girls and women surviving the war at home" (Shange 2018, 40). At home, as in the world, the Black girls whom Shange encountered in the Bay Area school were unprotected. In the plantation fields and within the master's house there was no distinction between the labor of Black men and women-women were required to labor just as hard though sometimes in different capacities. Indeed, the indistinguishability between male and female labor exploitation exemplifies the "theft, regulation and destruction of black women's sexual and reproductive capacities" (Hartman 2016, 166). This social liquidation exceeds the present demands of Black female labor, articulating one of slavery's afterlives, a common condition of Black [women's] being in the wake.

Reproductive labor is further marginalized by reformist interest in protecting the Black masculine. Despite the obvious-"Black women and girls bear the brunt of the labor associated with state violence and captivity" (Shange 2018, 45)-violence against Black people is typically recognized when it is enacted on film against the unarmed Black man. Alternatively, Black girlhood is granted no protections from either the state or political progressives. The destruction of kinship relations and the unmothering of the Black woman denies the Black girl her mother's protection. Yet as Mother Spillers has emphatically reminded us, "African Americans, under the press of a hostile and compulsory patriarchal order... [exercise] a degree of courage and will to survive that startles the imagination even now" (Spillers 1987, 75). Queered kinship reflects a praxis of resistance that enable[s/d] the Black woman to survive and, as Auntie Omise'eke Natasha Tinsley reminds us, "[connect] in ways that commodified flesh was never supposed to" (Tinsley 2008, 199).

Plantation relations required the formation of Black queered kinship and are replicated in urban, rural, and suburban Black geographies. African kinships, names, and 
traditions were rendered unnecessary baggage for which there was no room on the ship. Names were assigned to the new arrivals: Mammy, Sapphire, and Jezebel. Postemancipation Black women arose from a girlhood "ruined" by the "awful fate" that these names held, clinging to the elastic kinship formations that had emerged on the plantation (Hartman 2019, 91; 114; 198). Standing in stark contrast to the white, heteropatriarchal order, this queered kinship was pathologized. The meticulous ungendering that took place in the Middle Passage and on the plantation necessitated that the black woman assume the duties of her husband-overseeing dependents, who included biological and nonbiological children, cousins, aunties, parents, and grandparents as well as the men of the family and the husband himself-concretizing her unknowability in the national consciousness.

In more ways than one, Black queered kinship is untethered to heterosexuality. Auntie Tinsley's outline of the erotic bonds between African women in the holds of the slave ship traces Black queerness to the Atlantic, a site of crosscurrents or "theoretical and ethnographic borderlands at sea, where elements or currents of historical, conceptual, and embodied maritime experience come together to transform racialized, gendered, classed, and sexualized selves" (Tinsley 2008, 192). Significantly, it is only through an understanding of conjuring that we can also understand the Black Queer Atlantic, its people and their descendants, and the Black queerness that thrives in our communities today. By looking to Mother M. Jacqui Alexander's rejection of the "narrow conceptions of the factual," Auntie Tinsley identifies the need for a "fluid embodied-imaginary," one that recognizes an opaque, liquid amalgamation of past, present, and future (194). In doing so, she recognizes "an epistemology rooted in the body" as emphasized by E. Patrick Johnson's articulation of quare studies-a Black southern US inflection of the white, anti-Black field of queer studies (Johnson 2001, 9). The churning, lapping, tempestuous presence of history evokes a material awareness-an erotic.

Though the ancestral voices may be difficult to hear over the ocean's waves, the erotic positions us to identify the presence of not just fear during the Middle Passage, but also the intense need for encounter and touch. This erotic, as explained by Grandmother Audre Lorde, provides us with the power to experience feeling to the fullest extent, underlining our capacities for pleasure (Lorde 2007). Ungendering works to mutilate Black women's sexuality and subjugate feminine will, but they are revived through the use of the erotic. The deep participation enabled by the erotic reinvigorates the entanglement of mind/body/spirit and empowers the Black woman to resist the isolated position to which she has been assigned (for example, by the denial of her capacity to mother). Thus, the erotic materializes as a queer social practice in which play aunties, mamas, and grandmas are forged in an act of refusal and a demand for love.

\section{Praxis: Queer Black Matriarchy}

And I think my mom . . . she died very young, [and] just had all these dreams and hopes and she wanted me to live them for her so she literally like buried those things in me and decided to nurture me so that I could do the things she couldn't, and I've always said that my mother died so that I could live . . - - Kyla

In Black queer theory, play aunties reflect the femme-authoritative performance enacted by elder lesbians who are neither warm enough to be considered mamas nor wise 
enough to be designated grandmas (Shange 2018). Additionally, we may think of the role of "big sisters," or those women similar in age who share similar life experiences but are more knowledgeable, charismatic, and confident and therefore serve as guides to their younger siblings. Each of these kinship roles adheres to a characterization of maternity-specifically in the prevalence of a reproductive capacity that includes the disciplining of the younger community member. Queered kinship roles reconstruct the unmothered Black woman and restore her as an empowered member of the family. The intimacy of these "deeply de-sexualized" relationships reflects a notion of elastic kinship that answers Mother Hartman's call to "[counterinvest] in the body as a site of possibility" (Hartman 1997, 51; Shange 2018, 47). In doing so, we can understand Black mothering over the past half millennium as, in the words of Auntie Alexis Pauline Gumbs, "a creative practice defined not by the state, but by our evolving collective relationship to each other, our moments together and a possible future" (Gumbs 2016, 29). Counterinvestment enables us to see the "enslaved women [that] fled the plantation . . . utilized abortifacients rather than reproduce slaves; practiced infanticide rather than sentence their children to social death ... gave birth to children as testament to an abiding knowledge of freedom contrary to every empirical index of the plantation; and yearned for radically different ways of being in the world" (Hartman 2016, 167). In conjunction with the erotic, counterinvestment calls attention to the embodiment of mothering as well as the emotional/spiritual commitment that it entails. Counterinvestment in the Black body, then, enables us to see Black mothering not as pathological reproduction or economic function but as self-definition and affirmation for the future.

The disciplinary guidance enacted by elder matriarchal kin is a necessary characteristic of the relationship between elder kin and youth in that it presupposes the survival and sustenance of the Black community. Although these articulations vary across the geography of the African diaspora, our common conditions point members toward the "structural transformation of the lived condition of marginal communities" (Cohen and Jackson 2016, 777). The cumulative knowledge-experience of our foremothers leads us to/constructs Black liberation. These disciplinary tactics are passed down from matriarchal kin to youth, who, with time, themselves become practitioners of mothering. Contemporary organizations such as Black Lives Matter, BYP100, and BlackGirlsTravel are enveloped within the global movement for Black lives. ${ }^{3}$ Significantly, each of these organizations was founded and organized by queer Black women: Patrisse Cullors, Alicia Garza, and Opal Tometi; Charlene Carruthers; and Kyla, respectively. There are clear indications that these women draw heavily from the work of radical matriarchal elders/ancestors including Grandmothers Harriet Tubman, Ida B. Wells, Anna Julia Cooper, Ella Baker, Fannie Lou Hamer, Assata Shakur, and Angela Davis.

Of particular interest to me is Grandmother Ella Baker, whose youth-oriented activism, exemplified through her work with the Student Nonviolent Coordinating Committee (SNCC), is widely drawn from in contemporary Black activism. Mother Baker's call to understand who your people are, which has been taken up especially in BYP100 organizing tactics, draws attention to the necessity of queered kinship relations in the struggle for Black liberation. ${ }^{4}$ Black Lives Matter LA chapter leader Mother Melina Abdullah's reflection on womanist mothering cites Toni C. King and Alease Ferguson's work as “one of the first to politicize Black women's mothering from the perspective of Black womanhood" (Abdullah 2012, 60). The authors write: "African American mothers of the late nineteenth and twentieth centuries moved with a clear 
awareness of the objectification of womankind. And knowing this, they intentionally fed their daughters the tactical nourishment necessary to outwit oppressive forces" (60).

Queered kinship facilitates the reproduction of values, providing a map of Black liberation. Queer kin "raise the revolution" (Abdullah 2012). This praxis offers a significant element to our "wake work," which Mother Christina Sharpe describes as "a praxis of Black being in diaspora" (Sharpe 2016, 19). Wake work "insists and performs that thinking needs care and that thinking and care need to stay in the wake" (5). Sharpe's atemporal understanding of praxis and care encourages our comprehension of conjuring a new Black matriarchy, one that is never really new, but is carefully handed down through generations, from elder kin to youth, from ancestor to mother to daughter. One that is not just told through the spoken or written word but that is felt deep within our souls. One that allows for a daughter to become a sister/auntie/ mama. One that is always looking forward, always drawing from the past, and always taking care of those in the present, electrifying the erotic within.

\section{Resistance is not for Our Survival Alone ${ }^{5}$}

I went home to Miami . . . back to my old neighborhood, and I gave a presentation at my old high school ... I just sat in this auditorium and I just saw all these Black and Brown youth looking at me and ... one said to me, "You're not like us anymore you've left and you've had all these opportunities." And I was like, "Well what can I do?" And one was like, "Take us with you!" And I'm like, "Oh my god I wanna do that!" And so [on] that day I remember leaving the school saying, "I have to do this come hell or high water. I have to find a way to make this happen."-Kyla

Recently, I accompanied ten Black students on their first trip to Cuba. We spent twelvehour days venturing around the western part of the island filling our bellies with tropical fruits and filling our hearts with the knowledge of our ancestors. There were many instances of uninhibited Black joy on this trip. Students marveled at the swollen mangos and guava that dangled above our heads and occasionally fell to our feet, offering up their vibrant, sweet fruit. At one point a program director, herself a sister/auntie/ mama, told us that before we came to Earth-or as it has been written elsewhere, before I formed you in the womb-we had spoken with the Orishas. We told our Orishas our plans for our time on the earth, the divine purpose of our human form. Once encompassed in our mother's fluid, we forgot our purpose and came into the light of day unconscious of our formerly laid plan. Such is how we grew in the world. But our ancestors walk among and beside us, constantly orienting us toward our true path. Ancestors lay obstacles and aids attempting to reawaken us to our divine purpose. In this way, our whole lives are a remembering.

This is not to say that remembering is easy. Perhaps there are many who leave this world without ever having recalled their divine purpose. But it also may stand true that some of those whom we believe to have left us too soon have actually died remembering their purpose. Black mothers are those divine beings who have chosen to come to this world with it written in their heart that their resistance on this land is not for their survival alone. Before the birth of their firstborn, before their own first step, even before their first breath, they committed themselves to the protection of their children: those beautiful children whom Obatalá formed out of clay, leaving them tinged with the richness of the soil to which they will one day return; those beautiful children 
whose eyes squinted as their smiles widened at the sight of fruit stands, a beach dotted with Black families, and the drums that sparked a remembering of their celestial home.

I imagine that conversations between Black mothers and their Orishas must be very tender. I imagine that the soul of Harriet Tubman burned brightly as her ancestors told her of the brutality she was to enter into, nodding as she acknowledged that she, indeed, would do more than her fair share of community work. I imagine Mama Mamie and Mama Samaria embracing each other, shedding anticipatory tears for their yet-to-be-born sons. ${ }^{6}$ I imagine Tamika Washington nodding to Sojourner Truth, both uttering "I will shake every place I go to" (Sojourner Truth n.d.), as Washington turned to enter the world. ${ }^{7}$ I imagine that the love that one must have to enter this world as a Black mother must be the very thing that sends a single gentle ripple across a still lake, that can erupt a volcano, and gently rustle palm fronds on a humid day. It must be the love of a Black mother that has gotten us this far. It must be the love of a Black mother that will get us there.

I write this not only to calm the motherless child within myself, nor simply to acknowledge Kyla and the work of the many sisters/aunties/mamas/grandmas who have mothered, and will mother, me. Rather, I write this for all of the Black children who have lost their mother, for all of the African descendants who lose their mother, for those who are struggling to remember their divine purpose, and for those who can't remember that their mother's love is queer. That the Black woman who birthed, bathed, wept, and snuggled them is loved by and loves other Black women. For a Black woman to see the light in another Black woman, for a Black woman to love a Black woman is beautiful, wonderful, divine. I write this for the Black woman. May she always remember.

Acknowledgments. I would like to thank Kyla and all of the Black women in BlackGirlsTravel and Baltimore Abroad for mothering me, as well as the two anonymous reviewers for their generous comments and encouragement.

\section{Notes}

1 Kyla is a pseudonym for my dear mother/sister/teacher/friend for whom I write this piece. I chose this name based on a character in one of my favorite childhood books, Do Like Kyla (1993), written by Angela Johnson and illustrated by James Ransome.

2 All quotes are from Kyla, interview by Theresa Hice-Fromille, September 2018, transcript.

3 My understanding of such organizations aligns with those detailed by Cathy J. Cohen, who identified these as "the organizations that are part of a network of groups working under the broad framework of the Black Lives Matter movement" (Cohen and Jackson 2016, 777). I am extending this to include the work of any community-based/community-led organization that centers the goal of Black liberation.

4 The question, "Who are your people?" is attributed to Ella Baker and used in her organizational tactics. I was made aware of this tactic through a conversation with BYP100 alum, Auntie Savannah Shange (Shange 2019).

5 See Abdullah 2012, 58.

6 Mamie Till and Samaria Rice are the mothers of Emmett Till (1941-1955) and Tamir Rice (2002-2014), respectively.

7 Michelle "Tamika" Washington, a Philadelphia LGBTQ mentor and activist, was the fifth of at least twenty-two Black trans women living in the United States to be murdered in 2019.

\section{References}

Abdullah, Melina. 2012. Womanist mothering: Loving and raising the revolution. Western Journal of Black Studies 36 (1): 57-67. 
Cohen, Cathy J., and Sarah J. Jackson. 2016. Ask a feminist: A conversation with Cathy J. Cohen on Black Lives Matter, feminism, and contemporary activism. Signs: Journal of Women in Culture and Society 41 (4): 775-92.

Gumbs, Alexis Pauline. 2016. M/other ourselves: A Black queer feminist genealogy for radical mothering. In Revolutionary mothering: Love on the front lines, ed. Alexis Pauline Gumbs, China Martens, and Mai'a Williams. Oakland, Calif.: PM Press.

Hartman, Saidiya. 1997. Scenes of subjection: Terror, slavery, and self-making in nineteenth-century America. New York: Oxford University Press.

Hartman, Saidiya. 2007. Lose your mother: A journey along the Atlantic slave trade. New York: Farrar, Straus and Giroux

Hartman, Saidiya. 2016. The belly of the world: A note on black women's labors. Souls 18 (1): 166-73.

Hartman, Saidiya. 2019. Wayward lives, beautiful experiments: Intimate histories of social upheaval. New York: W. W. Norton \& Company.

Johnson, E. Patrick. 2001. "Quare" studies, or (almost) everything I know about queer studies I learned from my grandmother. Text and Performance Quarterly 21 (1): 1-25.

Lorde, Audre. 2007. Sister outsider. New York: Crossing Press.

Shange, Savannah. 2018. Play aunties and dyke bitches: Gender, generation, and the ethics of black queer kinship. The Black Scholar: Journal of Black Studies and Research 49 (1): 40-54.

Shange, Savannah. 2019. Personal communication.

Sharpe, Christina. 2016. In the wake: On blackness and being. Durham, N.C.: Duke University Press.

Sojourner Truth Memorial Committee. n.d. Sojourner's words and music. https://sojournertruthmemorial. org/sojourner-truth/her-words/.

Spillers, Hortense. 1987. Mama’s baby, papa’s maybe: An American grammar book. Diacritics 17 (2): 65-81. Tinsley, Omise'eke Natasha. 2008. Black Atlantic, queer Atlantic: Queer imaginings of the middle passage. GLQ: A Journal of Lesbian and Gay Studies 14 (2-3): 191-215.

Theresa Hice-Fromille is a Black mother and graduate student in the Department of Sociology at the University of California, Santa Cruz. Her dissertation investigates Black youth identity and communitybased roots travel initiatives. thmajohn@ucsc.edu

Cite this article: Hice-Fromille T (2021). The Queerness of Black Matriarchal Praxis. Hypatia 36, 547-554. https://doi.org/10.1017/hyp.2021.37 